\title{
EQUITABLE ESTOPPEL AND THE STATUTE OF FRAUDS IN CALIFORNIA
}

Fifteen years ago the California Supreme Court decided in Monarco v. Lo Greco ${ }^{1}$ that a party is estopped to assert the Statute of Frauds if he would be unjustly enriched or when unconscionable injury would result to the other party who, in reliance on the oral agreement, was induced to materially change his position. This decision represented a substantial stride in the persistent extension by the California courts of the doctrine of estoppel to assert the Statute of Frauds. ${ }^{2}$ As many cases involving this question have been decided in the intervening years, this seems a propitious time to assess the impact of this ground-breaking decision.

\section{I}

THE STATUTE OF FRAUDS: ITS PURPOSES AND APPLICATION

\section{A. History of and Rationale for the Statute of Frauds}

The first Statute of Frauds was enacted in 1677 durmg the reign of Charles II, ${ }^{3}$ with the avowed purpose of preventing "many fraudulent practices, which are commonly endeavored to be upheld by perjury and subornation of perjury." At this time contract law was in its early stages of development, and jury trials were less reliable than they are today, as there were few rules of evidence and parties to the suit were not considered competent witnesses.5 Consequently, the possibility of perjury and fraud was considerably greater. The authors of the Statute chose not to attack the problem directly, but elected to achieve indirectly the ultimate purpose of preventing fraud by declaring certain types of agreements to be unenforceable if not reduced to writing. ${ }^{\circ}$

Notwithstanding developments in the law of contracts and in the adjudicatory process, virtually all states continue to require that certain agreements be in writing. ${ }^{7}$ Therefore, it is necessary to consider what functions are served by the Statute in its modern setting.

These fall into two categories. First, the requirement of a writing

135 Cal. 2d 621, 220 P.2d 737 (1950).

2 See Note, Part Performance, Estoppel, and the California Statute of Frauds, 3 Stan. L. REv. 281 (1951).

${ }^{3}$ See Costigan, The Date and Authorship of the Statute of Frauds, 26 HARv. L. REv. 329 (1913).

429 Car. 2, c. 3 (1677).

5 See Summers, The Doctrine of Estoppel Applied to the Statute of Frauds, 79 U. PA. L. REv. 440, 441 (1931).

${ }^{6}$ See 2 Street, Foundations of Legax LiabiLITy, 169-70 (1906).

7 The principal requirements for a writing in California are set forth in CAL. Crv. Code $\S \S 1624,2309$; CaL. Code of Crv. Proc. § 1973; CaL. Comsm. Code $\S$ 1206, 2201. 
serves an evidentiary function. ${ }^{8}$ In addition to the opportunity for fraud to be perpetrated througl perjury, there is ample possibility for bona fide disputes to arise over the question of whether a contract was in fact formed, or over the terms of an admitted contract. ${ }^{\circ}$ This evidentiary function is rooted in the practical hmitations of the adjudicatory process in making accurate determinations of fact.

The second purpose which the Statute serves is "cautionary": ${ }^{10}$ It serves to impress upon the contracting parties the importance of the agreement. As the requirements of mutual assent and consideration are ordinarily adequate to satisfy the cautionary function, this factor has greater importance in the case of informal transactions than in commercial agreements.

Reduction of contracts to writing unquestionably makes the task of settling subsequent disputes concerming the agreement much easier. ${ }^{11}$ Professor Corbin, a critic of the Statute, has conceded "that the statute renders some service by operating in terrorem to cause important contracts to be in writing."12

On the other hand, it has been suggested that one effect of the Statute has been to increase litigation. ${ }^{13}$ One also wonders whether the Statute is not frequently used as a means for a party to avoid a contract which is no longer attractive rather than as a good faith defense. ${ }^{14}$ In addition, the relationship of the functions of the Statute to the determination of particular litigation should be distinguished from the Statute's influence

${ }^{8}$ For a discussion of the functions of formal requirements, see Fuller, Consideration and Form, 41 CoLUM. L. REv. 799 (1941).

${ }^{8}$ It is interesting to note that the California Commercial Code $\$ 2201(1)$ does not require all of the terms to be included in the writing. The writing must be signed by the party to be charged and must indicate that a contract was formed for the sale of goods. Such a contract will be enforced up to the quantity indicated in the writing, even if other terms are missing.

10 Fuller, supra note 8, at 800. Professor Fuller also suggests a third function which he calls a "channeling" function. This function serves to provide a basis for distinguishing the legal from the non-legal. Referring to the Statute of Frauds, Professor Fuller states, "[It] has only a kind of negative canalizing effect in the sense that it indicates a way by which one may be sure of not being bound." Id. at 802. As this Comment will slow, it is doubtful that the statute even has this "negative canalizing effect."

11 This point, lowever, should not be overstated. Even with the contract reduced to writing, the task of interpretation still remains; only the determination of the literal terms of the contract is facilitated by a writing. Moreover, the possibility for fraud is not removed entirely, merely by requiring the contract to be in writing. See Summers, supra note 5, at 460 .

122 CorbIN, Contracts $\$ 275$, at 13 (1950).

132 CoRBn, ConTracts $\S 275$, at 5 (1950): "It is at least as probable that but for the statute there would have been fewer broken promises and less litigation."

14 See, e.g., Ellis v. Mihelis, 60 Cal. 2d 206, 215, 384 P.2d 7, 12, 32 Cal. Rptr. 415, 420 (1963): "So far as appears, the defense now urged was an afterthought, raised for the first time when defendants had already obtained everything for which the written authorization could have been important to them, namely, the certainty of full performance by plaintiff." 
on whether future contracts are in writing. Thus, although the facts of a particular case may indicate that the purpose of the Statute have been satisfied, strict enforcement of its terms might be justified on the grounds of preserving the in terrorem effect of the Statute on future contracts. To determine whether enforcement of the Statute is justified it is necessary to determine first, whether the purposes of the Statute are still viable, and second, whether enforcement of oral agreements would debilitate the prophylactic function of the Statute.

While there is hittle empirical evidence, the weight of modern authority is of the opinion that the modern purposes of the Statute lack vitahity. ${ }^{15}$ Also, if enforcement of the oral agreement is limited to cases in which it would be particularly unjust to the plaintiff to permit the defendant to invoke the Statute of Frauds, then it is doubtful that the Statute would be deprived of its in terrorem effect or its cautionary function. Moreover, there is a paucity of evidence which might shed light on

15 See, e.g., Corbin, The Uniform Commercial Code-Sales; Should It be Enacted?, 59 YALE L.J. 821, 829 (1950): "The writer's study of the cases . . . has fully convinced him as follows: 1. that belief in the certainty and uniformity in the application of any presently existing statute of frauds is a magnificent illusion; 2. that our existing judicial system is so nuch superior to that of 1677 that fraudulent and perjured assertions of a contract are far less likely to be successful; 3 . that from the very first, the requirement of a signed writing has been at odds with the established habits of men, a habit of rehance upon the spoken word in increasing millions of cases; 4 . that when the courts enforce detailed formal requirements they foster dishonest repudiation without preventing fraud ...." For a defense of the Statute in its modern setting, see Llewellyn, What Price Contract?-An Essay in Perspective, 40 YALE L.J. 704, 746-48 (1931).

The California response to this controversy has been somewhat ambiguous. At times the courts have recognized that there are definite purposes and justifications for the Statute. See, e.g., Pacific Southwest Dev. Corp. v. Western Pac. R.R., 47 Cal. 2d 62, 301 P.2d 825 (1956) (contract to employ real estate agent). More often no reference to the purposes of the Statute are made by the courts. See, e.g., Monarco v. Lo Greco, 35 Cal. 2d 621, 220 P.2d 737 (1950).

This controversy is different from the related issue of the proper role of the courts in disposing of Statute of Frauds cases. An example of the latter question may be seen in the case of Sunset-Sternau Food Co. v. Bonzi, 60 Cal. 2d 834, 389 P.2d 133, 36 Cal. Rptr. 741 (1964). Justice Tobriner, speaking for the majority said, "Surely the courts do not seek to invalidate bona fide transactions by the inported application of esoteric legalisms. Our task is not to block the business pathway but to clear it, defining it by guide-posts that are reasonably to be expected." "Id. at 843,389 P.2d at 139, 36 Cal. Rptr. at 747 (1964). The najority was countered in the dissent by Justice Peters, who stated, "But the Legislature has decided that the danger of fraud in enforcing oral contracts outweighs the danger of injustice ... . That pohicy should not be emasculated by the courts." Id. at 846,389 P.2d at 141, 36 Cal. Rptr. at 749 (1964).

Notwithstanding what appears to be a disfavorable attitude of the courts towards the Statute, the legislative trend has been in the direction of expanding rather than restricting the scope of the writing requirement. Morcover, the Legislature has been hittle help in providing an articulation of the purposes behind the writing requirement. See note 120 infra. Given this state of affairs it is not surprising that the judicial response to Statute of Frauds cases has been analytically unclear. 
whether it is the presence of the Statute of Frauds, rather than independent considerations which causes important contracts to be reduced to writing. ${ }^{16}$

\section{B. Interests in Competition with the Purposes of the Statute}

Juxtaposed against the interests which the Statute attempts indirectly to protect are competing interests supported by long-established policies. Upon formation of the agreement, the parties have what has been termed an "expectancy" interest in the benefits of their bargain. ${ }^{17}$ If the plaintiff has been induced by the defendant to detrimentally change his position, there is a "reliance" interest. To the extent the defendant has been unjustly enriched by the plaintiff's performance, the latter lias a "restitution" inţerest.

While the Statute seeks to prevent a contract which was not made from being enforced, strict enforcement of the Statute may result in an injustice to the plaintiff when an oral agreement has in fact been made. Thus at the outset the Statute placed in opposition the rights of the defendant under the Statute and the interests of the plaintiff in having the oral agreement enforced; further, it directed protection of the defendant. Since in any given case a particular contract either was or was not formed, such conflict is necessary only if the fact determination process is ineffective. Moreover, it is justifiable only to the extent the functions of the Statute have continuing vitality. As suggested above, ${ }^{18}$ the experience of recent years casts doubts upon both of these conditions. This would suggest that within the context of the modern setting, resolution of the question of whether a particular oral agreement sliould be enforced requires a balancing of the reliability of the fact determination process against the prophylactic purpose of the Statute of Frauds.

\section{The Development of the Doctrine of Equitable Estoppel in Statute of Frauds Cases}

The doctrine of estoppel is a technique for determining which contracts will be enforced notwithstanding failure to comply with the

16 First, in many instances, it is quite possible that even after the passage of almost 300 years, many persons are unaware of the requirement for a writing in the particular case involved. See Sparks, Contracts to Make WirLs, 44-45 (1956). Second, many contracts may be reduced to writing to avoid problems of interpretation. Finally, a contract may be put in writing to prevent the other party from denying its existence. For an empirical study analyzing the role of the Statute of Frauds in commercial transactions, see Comment, The Statute of Frauds and the Business Community: A Re-Appraisal in the Light of Prevailing Practices, 66 YaIE L.J. 1038 (1957).

17 The terminology for the various interests of the plaintiff has been borrowed from Fuller \& Perdue, The Reliance Interest in Contract Damages, 46 YaLE L.J. 52, 53-54 (1936).

18 See text accompanying notes 15-16 supra. 
Statute of Frauds. The application of the doctrine of estoppel represents a compromise between the two extremes of complete abrogation of the Statute and strict enforcement of its terms. Although the historical development of the doctrines of part performance and estoppel to assert the Statute of Frauds have received extensive treatment elsewhere, ${ }^{10}$ understanding of the present status of the doctrine of estoppel requires some consideration of their development.

Shortly after its original enactment, it was recognized that the Statute of Frauds should not be enforced under certain circumstances. ${ }^{20}$ Originally relief was limited to part performance cases in contracts for the sale of land. ${ }^{21}$

The classic case of part performance arises where the plaintiff takes possession of and makes improvements on real property, ${ }^{22}$ or incurs some other detriment. ${ }^{23}$ It is important to note that the requirements for part performance satisfy the evidentiary purpose of the Statute. ${ }^{24}$ The plaintiff's part performance must evince the existence of a contract. Moreover, the plaintiff's possession must be with the consent of the defendant. ${ }^{25}$ Without possession, payment of the purchase price alone would not be sufficient to invoke the doctrine. ${ }^{26}$ The courts in developing the doctrine of part performance have borrowed the principles of estoppel, but these principles have been tempered in order to msure that the purposes of the Statute are not thwarted. Although the courts have not always articulated or stressed the relationship between the part performance doctrine and the aims of the Statute of Frauds, ${ }^{27}$ this rela-

10 See, e.g., Summers, supra note 5; Note, 3 Stan. L. REv. 281 (1951).

20 See Pound, The Progress of the Law, 1918-1919, Equity (Concluded), 33 Harv. L. REv. 929, 939 (1920). For evidence suggesting that the Statute's "framers never intended the statute to prevent the giving of equitable relief in the part-performance cases," see Costigan, supra note 3 , at 344 .

21 For a discussion of the doctrime of part performance in California, see Note, 3 Stan. L. REV. 281 (1951). Part performance is generally considered an extension of the principles of equitable estoppel and in many cases the elenients of botly are present. See, e.g., Summers, supra note 5, at 447; 3 Writrston, Contracts § 533, at 783 (3d ed. 1957).

22 E.g., Magee v. Magee, 174 Cal. 276, 162 Pac. 1023 (1917). The Restatement of Contracts § 197 (1932), and dicta in some cases, e.g., Calanchini v. Branstetter, 84 Cal. 249, 24 Pac. 149 (1890), suggest that possession alone may be enough; but in all cases in which the contract has been enforced there has been some detriment suffered by the plaintiff in addition to taking possession.

23 See, e.g., Halloran v. Isaacson, 95 Cal. App. 2d 357, 213 P.2d 19 (1949).

24 See 2 Corbin, Contracts $\$ 425$ (1950).

25 E.g., Wolfsen v. Hathaway, 32 Cal. 2d 632, 198 P.2d 1 (1948).

26 E.g., Anderson v. Stansbury, 38 Cal. 2d 707, 242 P.2d 305 (1952).

27 At times the courts have stressed the relationship of the parties' conduct to estabhishing the contract. See, e.g., Hambey v. Wise, 181 Cal. 286, 184 Pac. 9 (1919); Baker v. Bouchard, 122 Cal. App. 708, 10 P.2d 468 (1932). But more frequently no mention is made of this factor. See, e.g., Halloran v. Isaacson, 95 Cal. App. 2d 357, 213 P.2d 19 (1949). 
tionship is manifest in the requirements for invoking the part performance doctrine.

The doctrine of estoppel developed upon somewhat different theoretical underpinnings. At an early date courts of equity would step in to enforce contracts otherwise barred by the Statute in order to prevent an actual fraud. ${ }^{28}$ Despite frequent references to fraud prevention throughout the development of the doctrine of equitable estoppel, it is abundantly clear that the courts do not mean fraud in the usual sense of the word. ${ }^{29}$ Application of the estoppel doctrine was originally confined to fact situations in which the defendant made representations which went directly to the requirement of the Statute itself: $:^{30}$ where the defendant made a misrepresentation regarding the existence of a fact which, if true, would obviate the need for the writing, ${ }^{31}$ a representation that the oral agreement would be reduced to a writing at a subsequent time, ${ }^{32}$ or a representation that the defendant would not rely on the Statute..$^{33}$ In addition, the plaintiff also had to demonstrate that he was injured as a result of reliance on the defendant's representation.

Monarco v. Lo Greco ${ }^{34}$ was a significant departure from earlier California case law in that the court explicitly rejected the notion that the representation must go directly to the requirement of the Statute of Frauds. ${ }^{35}$ The facts of the Monarco case were as follows: $C$ moved with his mother and stepfather to California, where the parents purchased agricultural property, which they held in joint tenancy. When $C$ was eigliteen years old, he decided to leave hoine and seek independent einployment. His mother and stepfather orally promised that if $C$ would stay home and work, they would leave him the bulk of the property. $C$

28 See Summers, supra note 5 , at $443-45$.

29 See 2 Corbis, Contracts $\$ 429$, at 470-71 (1950). In Monarco v. Lo Greco, 35 Cal. 2d 621, 623, 220 P.2d 737, 739 (1950), the court said: "Such fraud may inhere in the unconscionable injury that would result from denying enforcement of the contract after one party has been induced by the other seriously to change his position in reliance on the contract."

30 See Summers, supra note 5. Restatearent, Contracts \& 178, comment $f$ (1932): "Tliough there las been no satisfaction of the Statute, an estoppel may preclude objection on that ground in the same way that objection to the non-existence of other facts essential for the establishment of a riglit or a defense may be precluded. A misrepresentation that there has been such satisfaction if substantial action is taken in reliance on the representation, precludes proof by the party who made the representation that it was false; and a promise to make a memorandum, if similarly relied on, may give rise to an effective promissory estoppel if the Statute would otherwise operate to defraud."

31 E.g., Fleming v. Dolfin, 214 Cal. 269, 4 P.2d 776 (1931).

82 E.g., Seymour v. Oelrichs, 156 Cal. 782, 106 Pac. 88 (1909).

33 E.g., Vierra v. Pereira, 12 Cal. 2d 629, 86 P.2đ 816 (1939).

3435 Cal. 2d 621, 220 P.2d 737 (1950).

35 Some cases, e.g., Tuck v. Gudnason, 11 Cal. App. 2d 626, 54 P.2d 88 (1936), prior to Monarco granted relief where no direct representation going to the Statute itself was made. 
remained and worked on the farm pursuant to the oral agreement, abandoning any opportunity of further education or to accumulate property of his own, and receiving only room, board, and spending money. When $C$ suggested that he receive a present interest in the property after he was married, his stepfather reaffirmed his promise that $C$ would receive the bulk of the property when the surviving parent died. Shortly before dying, the stepfather executed the necessary conveyances to destroy the joint tenancy and left the property to his grandchild.

$C$ sued on the contract. The California Supreme Court granted rehef for $C$, stating that the doctrine of estoppel would be applied where an unconscionable injury would result from denying enforcement of the contract after one party has been induced by the other to materially change his position in rehance on the contract, or where the party relying on the Statute would be unjustly enriched. "In reality it is not the representation that the contract will be put in writing or that the statute will not be invoked, but the promise that the contract will be performed that a party relies upon when he changes his position because of it." ${ }^{130}$ The court suggested an important qualification: If the quasi-contractual remedy for the value of the services rendered had been adequate, then the contract would not have been enforced. The remedy in the case at hand was considered inadequate, however, because the services were "of a peculiar nature involving the assumption or continuation of a close family relationship."

The Monarco decision opened the door for a broad application of the estoppel doctrine. The test, while couched in fairly broad and general terms, nevertheless envisions some limitations on its application. As stated above, ${ }^{38}$ whether a contract should be enforced involves a balancing of the rehability of the fact determination process against the prophylactic purpose of the Statute. This raises the question whether the doctrine of estoppel as it is applied in California, is an effective technique for so resolving these cases.

\section{II}

APPLICATION OF THE ESTOPPEL DOCTRINE IN CALIFORNIA

The basic elements necessary for application of the doctrine of estoppel as set forth in Monarco relate to the conduct of the defendant which induces the reliance and the conduct of and injury to the plaintiff in reliance thereon. While these factors are necessarily interrelated, analysis is simphified if they are treated separately.

${ }^{36}$ Monarco v. Lo Greco, 35 Cal. 2d 621, 626, 220 P.2d 737, 741 (1950).

37 Ibid.

38 See text accompanying note 18 supra. 


\section{A. Conduct of the Defendant Which Induces the Plaintiff's Reliance}

As we have seen, the court in Monarco rejected the requirement that the defendant's representation go directly to the requirement of the Statute itself. ${ }^{39}$ The inherent unreasonableness of this limitation becomes clear when consideration is given to the explanations usually advanced for failure to reduce an agreenent to writing. There are four principal reasons for failure to ineet the requirements of the Statute of Frauds: (1) The plaintiff may have rehed on a promise by the defendant to subsequently reduce the oral agreement to a writing; (2) the plaintiff may have relied on a representation by the defendant that the Statute would not be relied upon as a defense; (3) the parties may not have realized that a writing was required; or (4) the parties may have honestly beheved that the requirements for a writing had been satisfied. Situations (1) and (2) imvolve representations by the defendant which go directly to the requirement of the Statute, and courts have traditionally held the defendant estopped to plead the Statute of Frauds in such cases. If such a representation is an essential ingredient of the case in which the defendant is estopped to plead the Statute, then recovery would be denied in examples (3) and (4), because in these cases there would be no occasion for such a representation to be made. The plaintiff's reliance in such cases, however, may be just as reasonable, and his injury as great, as in those cases in which a representation going to the requirement of the Statute is made. Moreover, the evidence of the contract may be as strong or stronger in those instances where the representation has not gone directly to the Statute. Therefore, the rejection of this distinction by the court in Monarco represents a salutary extension of the doctrine of estoppel.

The opinion of the court in Monarco is not completely clear as to whether any conduct by the defendant subsequent to the oral agreement is essential to apply the doctrine of estoppel. In Monarco there were express reaffirmations by the stepfather of his intention to perform the oral agreement. In the cases following Monarco in which the oral agreement has been enforced, there has been conduct by the defendant subsequent to the oral agreement which could at least imply the existence of the contract. ${ }^{40}$ At least one Califorma court ${ }^{41}$ has held that subsequent conduct is essential to the application of the doctrine of estoppel.

39 See text accompanying notes 30-33 supra.

40 See, e.g., De Hermosillo v. Morales, 146 Cal. App. 2d 819, 304 P.2d 854 (1956); Moore v. Day, 123 Cal. App. 2d 134, 266 P.2d 51 (1954); Goldstein v. McNeil, 122 Cal. App. 2d 608, 265 P.2d 113 (1954).

41 Parker v. Solomon, 171 Cal. App. 2d 125, 133, 340 P.2d 353, 359 (1959): "An allegation of misrepresentations going to the requirements of the statute of frauds is not a pre- 
It should be noted, however, that the courts have not generally addressed themselves specifically to the question of the need for such conduct. More often the cases are disposed of within the framework of the general test set forth in Monarco..$^{42}$ As a result of this uncertainty, it is unclear what it is that the plaintiff must rely upon. ${ }^{43}$

In contrast to the part performance cases, ${ }^{44}$ little attention is paid to whether the purposes of the Statute have been satisfied, and no effort has been made to analyze the conduct of the parties as evidence of the existence of the contract.

\section{B. Injury to and Conduct of the Plaintiff}

\section{Benefit to the Defendant by the Plaintiff's Performance}

The courts have attempted to reach a compromise position where the remedy of quantum meruit is available and adequate. In such cases, the contract will not be enforced, and the plaintiff is himited to a restitutionary remedy. But where quantum meruit is unavailable or does not provide adequate relief, the defendant may, where otherwise appropriate, be estopped to plead the Statute, and full enforcement of the contract will be allowed.

Accordingly, the element of benefit to the defendant arising from the plaintiff's performance is of importance in two distinct respects. First, the existence of benefit to the defendant determines the availability of a remedy of quantum meruit, whicl in turn will determine whether the plaintiff's remedy will be himited to restitution. Second, it bears on the determination of whether the defendant should be estopped to plead the Statute of Frauds. Thus, while the unjust enrichment of the defendant is not an essential element for the application of the doctrine of estoppel, it is sufficient provided the plaintiff has rehed on the oral agreement in so benefitting the defendant. It is helpful to analyze these cases on the basis of the type of transaction in question, since the courts have drawn further distinctions on this basis.

Most of the cases subsequent to Monarco in which the doctrine of estoppel has been at issue, have involved contracts to make wills. These

requisite to a finding of an estoppel to assert the statute. . . . Nevertheless there must be an allegation of conduct by the party against whom the estoppel is asserted which would make it inequitable for him to rely on the statute as a defense. It is obvious that the mere making of an oral agreement which is within the statute is not in and of itself sufficient to estop the promisor from raising the statute as a defense."

42 See, e.g., De Hermosillo v. Morales, supra note 40; Goldstein v. McNeil, supra note 40.

43 In Monarco the court at one point speaks of reliance on the contract and at a later point of reliance on the promise that the contract will be performed. $35 \mathrm{Cal} .2 \mathrm{~d}$ at 623,626 , 220 P.2d at 739,741 (1950).

44 See text accompanying notes 22-27 supra. 
are of two main types. In the first, the promise to will property to the plaintiff is given in exchange for the plaintiff's promise to render services to the testator. In the second, the promise to make a particular testamentary disposition is given in exchange for the promisee's transfer of property, by will or otherwise, to the decedent or to some other designated beneficiary. In contracts to make a will in exchange for services, the remedy of quantum meruit is frequently available and adequate, in which case the contract will not be enforced.$^{45}$ Whether quantum meruit is an "adequate" remedy will depend on whether the plaintiff's services can be adequately compensated in money; ${ }^{46}$ in addition, it has been stated that a restitutionary remedy may be inadequate where the plaintiff has substantially changed his position, such that the reasonable value of his services would be insufficient to place the plaintiff in his original position. ${ }^{47}$

Where the services performed by the plaintiff were of a personal nature, such as providing his companionship and society, it has been held that they are so peculiar and personal as to render them impossible to value by any pecumiary standard..$^{48}$ The factor of a substantial change of position has never been carefully delineated. No case has been found allowing full enforceinent of the oral contract on this criterion alone. ${ }^{49}$ An allegation that the plaintiffs "changed their own mode of life and denied themselves outside pleasures" was held insufficient. ${ }^{50}$ In those cases where the basis for recovery is that the services are not coinpensable in money, the courts do not require as substantial a change of position by the plaintiff as is required in other types of contracts. ${ }^{51}$

In the second type of contract to make a will where the plaintiff

45 Kobus v. San Diego Trust \& Sav. Bank, 172 Cal. App. 2d 574, 342 P.2d 468 (1959); Palmer v. Phillips, 123 Cal. App. 2d 291, 266 P.2d 850 (1954); Chahon v. Schneider, 117 Cal. App. 2d 334, 256 P.2d 54 (1953); Jirschil v. Farmers \& Merchants Nat'l Bank, 107 Cal. App. 2d 405, 237 P.2d 49 (1951).

16 Monarco v. Lo Greco, 35 Cal. 2d 621, 220 P.2d 737 (1950); Horstmann v. Sheldon, 202 Cal. App. 2d 184, 220 Cal. Rptr. 735 (1962); Ward v. Wrixon, 168 Cal. App. 2d 642, 336 P.2d 640 (1959); De Hermosillo v. Morales, 146 Cal. App. 2d 819, 304 P.2d 854 (1956).

47 See, e.g., Palmer v. Phillips, supra note 45 ; Chahon v. Schneider, supra note 45.

48 Ward v. Wrixon, supra note 46; Walker v. Calloway, 99 Cal. App. 2d 675, 222 P.2d 455 (1950). In practice, the courts seem to draw the line, almost mechanically, on the basis of whether the plaintiff is a close relative of the promisor. Compare Horstmann v. Sheldon, supra note 46, and De Hermosillo v. Morales, supra note 46, with Kobus v. San Diego Trust \& Sav. Bank, supra note 45 . One case, Ward v. Wrixon, supra note 46 , has enforced the contract where the plaintiff was not a relative of the promisor.

49 It would seem that the requirements would be at least as great as in the case of normal employinent contracts. See text acconipanying notes 62-66 infra.

50 Palıner v. Phillips, 123 Cal. App. 2d 291, 294, 266 P.2d 850, 852 (1954).

E1 Compare De Hermosillo v. Morales, 146 Cal. App. 2d 819, 304 P.2d 854 (1956), with Ruinello v. Murray, 36 Cal. 2d 687, 227 P.2d 251 (1951). 
promises presently to transfer property, ${ }^{62}$ keep property in joint tenancy ${ }^{53}$ or make a reciprocal will ${ }^{54}$ in exchange for the promisor's promise to will the property so received to a particular beneficiary, the courts have enforced the contract, at least in those cases where the promisor received the benefit of the plaintiff's performance. In such a case the remedy of quantum meruit is inappropriate, at least where, as is usually the case, the beneficiary is not the person who transferred the property. ${ }^{65}$ The defendant would be unjustly enriched if he were permitted to keep the benefits of the bargain.

The contract to make a will cases, because of the informality of the formation process, present the greatest evidentiary problems. ${ }^{50}$ On the other hand, these contracts are usually among members of the family and are seldom reduced to writing. Enforcing them frequently conflicts with the policies regarding the requirements for executing a will, ${ }^{57}$ although that conflict is present, if to a lesser extent, even if the contract is in writing. The problem can be partially mitigated by the requirement of a higher standard of proof of the contract. While at times the courts have treated this as a requirement, ${ }^{58}$ it is more often ignored..$^{60}$

Insofar as the purposes of the Statute of Frauds are concerned, the distinction between services of a peculiar and personal nature from those which are not is irrelevant. Whether the oral agreement is enforced, however, often depends upon this factor, since it bears heavily upon the "adequacy" of the remedy of quantum meruit. As suggested above, the courts seem to be disposing of the issue of whether the remedy of quantum meruit is adequate with almost mechanical consistency. Since the factors which determine the adequacy of the remedy of quantum meruit

52 Rundell v. McDonald, 62 Cal. App. 721, 217 Pac. 1082 (1923). This case was decided on a theory of "part performance" at a time prior to the extension of the doctrine of estoppel. The considerations involved in this case are comparable to those in the estoppel cases, and the same result could easily be reached on an estoppel theory today. See also Van Fossen v. Yager, 65 Cal. App. 2d 591, 151 P.2d 14 (1944).

${ }^{53}$ Lake v. Jackson, 191 Cal. App. 2d 372, 12 Cal. Rptr. 652 (1961).

54 Notten v. Mensing, 3 Cal. 2d 469, 45 P.2d 198 (1935).

55 See, e.g., lbid.

56 See Sparks, Contracts to Make Wriss 22-38 (1956). The "cautionary" function of the formal requirement of a writing, see text accompanying note 11 supra, seems most applicable to contracts to make wills.

57 See Cax. Prob. Code $\$ \S 50-55$.

58 See, e.g., Notten v. Mensing, 3 Cal. 2d 469, 477, 45 P.2d 198, 202 (1935): "We are well aware that ... the temptation is strong for those who are so inclined to fabricate evidence giving color to the clain that the parties entered into ... an oral agreement. . . On the trial on the merits, the burden rests on the plaintiff to prove the oral agreement by full, clear and convincing evidence." (Emphasis added.)

59 See, e.g., Monarco v. Lo Greco, 35 Cal. 2d 621, 220 P.2d 737 (1950); De Hermosillo v. Morales, 146 Cal. App. 2d 819, 304 P.2d 854 (1956). 
are often unrelated to whether the particular contract was in fact formed, it would seem that the competing interests of the promisor and other beneficiaries are not adequately accommodated in many of these cases. The injustice to the other beneficiaries may be further aggravated where the plaintiff gets substantially more than the value of his services ${ }^{60}$ in those cases when recovery is not limited to quantum meruit.

On the other hand, if the elements of estoppel are present and the conduct of the parties strongly evidences the existence of the contract, to bimit recovery to an action in quantum meruit is perhaps too harsh on the plaintiff, especially when we consider that had the defendant not received the benefit of the plaintiff's performance, recovery on the contract might have been possible.

The himitation of recovery to quantum meruit is perhaps justifiable as a compromise position. The reason for this limitation probably stems more from the historical principle of denying equitable relief where the remedy at law is deemed adequate. ${ }^{61}$ Adequacy in this case does not involve whether the plaintiff's expectancy interest lias been vindicated.

In contrast to the contracts to make wills are the commercial contracts, either for services or sale of goods. In the normal commercial employment contract, the services are not of such a personal and peculiar nature and ordinarily are deemed compensable in money. Accordingly, the general rule is that the remedy of quantum meruit is adequate. ${ }^{62}$ Those cases in which the contract has been enforced contain exceptional features: either the plaintiff has given up valuable rights under an existing contract ${ }^{63}$ or suffered a $\operatorname{loss}^{64}$ in reliance on the oral agreement. It is not enough to have merely given up another job, unless it can be shown that the plaintiff's rights under the previous contract were so valuable that unconscionable injury would result if the oral contract were not enforced. ${ }^{65}$ While this distinction is of dubious validity either to the satisfaction of the purposes of the Statute or to the actual injury

60 See Walker v. Calloway, 99 Cal. App. 2d 675, 222 P.2d 445 (1950). Where the contract is enforced, the fact that the services were of a short duration is of no consequence, whereas if the action is in quantum meruit the duration of the services will be of considerable significance since the measure of recovery is the reasonable value of such services.

61 See, e.g., Monarco v. Lo Greco, 35 Cal. 2d 621, 626, 220 P.2d 737, 741 (1950). If the court so desired it could expand the restitution concept to permit the defendant to reimburse the plaintiff for out-of-pocket loss in rehiance on the oral agreement even though the defendant was not enriched. See generally Fuller \& Perdue, The Reliance Interest in Contract Damages, 46 YaLE L.J. 52, 373, 418-20 (1936-1937). See Minsky's Follies of Florida, Inc. v. Sennes, 206 F.2d I (5th Cir. 1953).

62 For a case holding the remedy of quantum meruit to be adequate, see Ruinello v. Murray, 36 Cal. 2d 687, 227 P.2d 251 (1951).

63 Seymour v. Oelrichs, 156 Cal. 782, 106 Pac. 88 (1909).

64 Hunt Foods v. Phillips, 248 F.2d 23 (9th Cir. 1957).

65 Ruinello v. Murray, supra note 62 . 
sustained by the plaintiff, ${ }^{68}$ it seems to represent an attempt to limit enforcement of the contract to situations where the plaintiff cannot be placed in the position he was prior to the oral agreement. ${ }^{.7}$

The contract for the employment of a real estate agent ${ }^{08}$ has received special treatment; here the Statute of Frauds has been strictly applied. ${ }^{60}$ Enforcement of real estate agency contracts has been limited to situations in which the agent has been induced to give up something of value, such as a contract of employment which satisfied the writing requirement, ${ }^{70}$ in reliance on the defendant's oral promise. The courts seem particularly concerned with protecting the promisor in these cases. ${ }^{71}$ Also, real estate agents can justifiably be charged with knowledge of the writing requirement. ${ }^{72}$

The legislature has provided the basis for recovery in oral contracts for the sale of goods in excess of 500 dollars when the defendant has received all or part of the performance. ${ }^{73}$ Prior to the adoption of the California Commercial Code, section 1624a of the California Civil Code provided that if the defendant accepted part of the goods or paid part of the price the entire contract was enforceable. ${ }^{74}$ Under section 2201(3) of the California Commercial Code, ${ }^{75}$ which replaced the above provision

60 See id. at 691, 227 P.2d at 254 (dissenting opinion).

67 See Traynor, Unjustifiable Reliance, 42 MnNs. L. REv. 11, 17-18 (1957).

68 See Cal. Crv. Code § 1624(5).

${ }^{60}$ See, e.g., Pacific Southwest Dev. Corp. v. Western Pac. R.R., 47 Cal. 2d 62, 301 P.2d 825 (1956).

70 Le Blond v. Wolfe, 83 Cal. App. 2d 282, 188 P.2d 278 (1948).

71 Pacific Southwest Dev. Corp. v. Western Pac. R.R., 47 Cal. 2d 62, 70-71, 301 P.2d 825, 831 (1956).

$72 I d$. at 70, 301 P.2d at 831. "Plaintiff is a licensed real estate broker and, as such, is presumed to know that contracts for real estate commissions are invalid and unenforceable unless put in writing and subscribed by the person to be charged." While this factor is not relevant to whether the purposes of the Statute have been satisfied, it is a material factor to consider insofar as the protection of the plaintiff's interests is a legitimate factor to balance against the interests which the Statute seeks to protect.

73 Technically, to the extent the Statutes authorize enforcement of an oral agreement, the basis for such enforcement is not the doctrine of estoppel. The principles involved are comparable, and analysis of the doctrine of estoppel is aided by considering how sale of goods cases are handled.

74 "(1) A contract to sell or a sale of any goods or choses in action of the value of five lundred dollars or upward shall not be enforceable by action unless the buyer shall accept part of the goods or choses in action so contracted to be sold or sold, and actually receive the same, or give something in earnest to bind the contract, or in part payment, or unless some note or memorandum in writing of the contract or sale be signed by the party to be charged or his agent in that behalf." Cal. Stat. 1931, ch. 1070, § 13. See Kurlan v. Columbia Broadcasting System, 40 Cal. 2d 799, 256 P.2d 962 (1953); Sousa v. First Cal. Co., 101 Cal. App. 2d 533, 225 P.2d 955 (1950).

75 CAI. COMM. CODE $\$ 2201$ (3): "A contract which does not satisfy the requirements of subdivision (1) [the writing requirement] but which is valid in other respects is enforceable ... (c) With respect to goods for which payment has been made and accepted or wbich have been received and accepted...." 
on January 1, 1965, if part payment is made or part of the goods are accepted by the defendant, the contract is enforceable only to the extent of the part payment or partial performance. It remains to be seen whether the entire contract will be enforced where the elements of estoppel are present, notwithstanding the statutory directive to the contrary. ${ }^{78}$ While this change is consistent with the policy of refusing to enforce the contract where the remedy of quantun meruit is available, it is subject to the saine criticisms. ${ }^{77}$

Another factor which may be determinative in a particular case is whether the plaintiff has fully performed. In some jurisdictions where the plaintiff has fully performed a contract which is required to be in writing because it could not be performed within one year, ${ }^{78}$ the remaining promise is enforceable notwithstanding the failure of the parties to comply with the writing requirement. ${ }^{79}$ In such a case it is not necessary to prove the elements of an estoppel. The status of California law is unclear. One case ${ }^{80}$ held that the remaining promise was still subject to the defense of the Statute. On the other hand, other $\operatorname{cases}^{81}$ have held that the Statute does not apply where there is nothing left for the defendant to do but pay the agreed compensation. Even if the contract cannot be enforced, perhaps the oral agreement may be used as evidence of the value of the services. ${ }^{82}$

76 Although the statutory language is quite clear, it seems quite possible that the courts will enforce the contract in its entirety where the facts are sufficient to apply the doctrine of estoppel. The courts have applied the estoppel doctrine to contracts for the sale of goods which, under the Sales Act, would otherwise be barred by the Statute. See, e.g., Goldstein v. McNeil, 122 Cal. App. 2d 608, 265 P.2d 113 (1954); Mosekian v. Davis Canning Co., 229 A.C.A. 121, 40 Cal. Rptr. 157 (1964).

77 See text accompanying notes 60-61 supra.

78 See, e.g., Cat. Civ. Code § 1624(1); Cat. Code Crv. Proc. § 1973(1).

79 Restatement, Contracts $\$ 198$ (1932): "Where any of the promises in a bilateral contract cannot be fully performed within a year from the time of the formation of the contract, all promises in the contract are within ... [the statute], unless and until one party to such a contract completely performs what he has promised." (Emphasis added.) This rule does not apply to contracts in other sections of the statute. Under the Cahifornia Commercial Code Section 2201, the same effect is achieved since the agreement will be enforced to the extent of the performance by the plaintiff.

80 Gressley v. Williams, 193 Cal. App. 2d 636, 14 Cal. Rptr. 496 (1961). The court relied primarily on Kobus v. San Diego Trust \& Sav. Bank, 172 Cal. App. 2d 574, 342 P.2d 468 (1959), a contract to make a will case.

81 E.g., Nesson v. Moes, 215 Cal. App. 2d 655, 30 Cal. Rptr, 428 (1963); Roberts v. Wachter, 104 Cal. App. 2d 271, 231 P.2d 534 (1951).

82 Offeman v. Robertson-Cole Studios, Inc., 80 Cal. App. 1, 13, 251 Pac. 830, 835 (1926): "Even though an oral contract may be unenforceable, the oral stipulations of the parties as to the compensation to be paid for services rendered under it are in the nature of admissions by them as to the reasonable value of such services and, while not conclusive, are admissible in evidence." 


\section{Character of the Plaintiff's Injury}

In the case where the plaintiff changes his position in reliance on the oral agreement, but where the defendant has not been benefitted, a quantum meruit remedy is not available. In this case the courts lave the alternatives of either enforcing the contract or denying recovery entirely. The court in Monarco stated that the oral agreement would be enforced where an unconsicionable injury would result from denying enforcement after one party had been induced by the other to seriously change his position in reliance on the contract. ${ }^{83}$ First, it must be determined whether the plaintiff las changed his position, and, second, whether the injury to him was serious.

Perhaps the strongest case for recovery is made where the plaintiff by a positive act has incurred an out-of-pocket loss in reliance on the oral agreement. In Carey $v$. Coombs, ${ }^{84}$ the defendant orally agreed to extend a contract which he had with a third party for timber rights. The defendant knew that the profitability of the plaintiff's purchase of the third party's contract rights depended upon the extension. In reliance on the oral agreement of extension, the plaintiff paid the third party 6500 dollars for lis rights under the contract. The plaintiff also paid the defendant $\$ 600$ for the extension and began felling timber. Shortly thereafter the defendant returned the check and renounced the contract. The court held the defendant was estopped to plead the Statute of Frauds.

The plaintiff's change of position may be found where lie affirmatively gives up an existing right. Thus im one case ${ }^{85}$ the oral contract of employment was enforced where the plaintiff gave up a contract of permanent employment.

The plaintiff may also change his position by forbearance from exercising an existing right in exchange for the defendant's promise. A contract to make a will was enforced in one case where the plaintiff abandoned a will contest in exchange for the decedent's promise to bequeath and devise property to the plaintiff. ${ }^{86}$ Where the plaintiff's conduct consists merely of forbearance from exercising an existing right it evinces the contract mucl less than where the plaintiff affirmatively abandons an existing right. The courts have been less inclined to grant relief where the plaintiff's change of position has amounted to mere forbearance from

8335 Cal. 2d 621, 623, 220 P.2d 737, 739 (1950).

84139 Cal. App. 2d 649, 294 P.2d 62 (1956). For another example of where the courts have applied the doctrine when the plaintiff expended money in rehance on the oral agreement, see Union Packing Co. v. Cariboo Land \& Cattle Co., 191 F.2d 814 (9th Cir. 1951), cert. denied, 342 U.S. 909, rehearing denied, 342 U.S. 934 (1952). 
exercising an existing right. ${ }^{87}$ In so doing, however, the courts have seemed less concerned with whether such conduct does little to corroborate the existence of the contract, than with the speculative nature of the injury. The latter consideration properly bears on the question of damages rather than on the question of whether the purposes of the Statute have been satisfied.

Under some circumstances recovery has been granted in contracts for the sale of goods where the statutory requirements considered above ${ }^{88}$ were not met. Recovery on the oral agreement was permitted in one case ${ }^{89}$ where in reliance on the defendant's promise to buy the plaintiff's fruit crop, the latter refrained from selling it to someone else. When the defendant finally repudiated the oral agreement, the plaintiff had to sell at a substantial loss because the fruit had dried out. The plaintiff's loss was due to the decrease in value of the fruit, not through a change in the market, but because the fruit had become overripe.

The farthest and perhaps inost questionable extension of the estoppel doctrine occurred in the case of Goldstein v. McNeil..$^{90}$ The plaintiff by oral agreement sold some used cars to the defendant, to be shipped from Shreveport, Louisiana to San Francisco. The defendant paid the plaintiff 910 dollars for caravan expenses and the plaintiff secured permits at a cost of 210 dollars. When the cars reached Fresno, California, the defendant refused to accept them. The plaintiff's tender was held to be in substantial compliance with the terms of the contract. After giving the defendant notice, the plaintiff sold the cars to a third party. The difference between the contract price and the amount reahzed by the plaintiff was $3,865.22$ dollars. The court recognized that normally refusal to accept the goods would not estop the defendant from asserting the Statute of Frauds, ${ }^{91}$ and that the payment of the 210 dollars by the plaintiff for the permits was not a substantial injury. The court found, however, that an unconscionable injury resulted "because of his performance of the contract he missed the very high market existing around the time of the contract and was caught in a sharp slump." ${ }^{\prime 22}$ To the extent the

87 See, e.g., Fallon v. American Trust Co., 176 Cal. App. 2d 381, 1 Cal. Rptr. 386 (1959) ("The forbearance here is ephemeral.")

88 See text accompanying notes 73-77 supra, for a discussion of the statutory requirements in contracts for sale of goods.

89 Mosekian v. Davis Canning Co., 229 A.C.A. 121, 40 Cal. Rptr. 157 (1964).

90122 Cal. App. 2d 608, 265 P.2d 113 (1954).

91 Id. at 611, 265 P.2d at 114-15. The court distinguished Booth v. A. Levy \& J. Zentner Co., 21 Cal. App. 427, 431, 131 Pac. 1062, 1064 (1913), where it was said: "It is a plain case where the seller chose to ship goods to a distant buyer who was bound by an oral agreement only. To hold that under such circumstances the buyer, who refuses to accept the goods is estopped to rely upon the statute would be to practically abrogate the statute of frauds."

02 Id. at 612, 265 P.2d at 115. In Moore v. Day, 123 Cal. App. 2d 134, 266 P.2d 51 
courts are prepared to follow this case, it seems that for all practical purposes the Statute of Frauds has been abrogated in contracts for the sale of goods for future delivery, since in most cases a fall in the market price is the explanation for the defendant's refusal to perform. ${ }^{93}$ Generally, however, the mere loss of the benefits of the bargain has not been a sufficient basis for recovery. ${ }^{94}$

The court in Monarco stated that the plaintiff must "seriously" change his position. .5 No clear line, however, separates the "serious" from the "non-serious" change of position. Recovery has been denied where the loss is speculative..$^{98}$ Although no case since Monarco has denied recovery on the basis that the amount was not substantial where an actual out-of-pocket loss was proven, it is doubtful that the oral agreement will be enforced where the detriment suffered by the plaintiff is relatively slight. ${ }^{.7}$

The seriousness of the injury to the plaintiff as a criterion upon which to himit the application of the doctrine of estoppel is at best only indirectly related to the purposes of the Statute. The gravity of the injury neither directly indicates the existence of the contract nor does it directly indicate that the plaintiff has reasonably relied upon the representations or promises of the defendant. To require that the plaintiff suffer a substantial injury may be explained as an attempt to deny enforcement where the plaintiff is, or may be restored to, his original position. The same justifications or criticisms which are applicable to limiting recovery to quantum meruit ${ }^{28}$ are also appropriate here.

\section{CONCLUSION}

While Monarco and most of its progeny have been will cases, the doctrine of estoppel has of course not been limited in its extension to such cases. ${ }^{99}$ There are some basic differences between the family con-

(1954), the contract was also enforced where the principal damage was the loss of profits due to the decline in the market. In Moore, however, there were repeated assurances by the defendant that he would accept the hean crop.

93 If the market had risen rather than fallen, the reasoning of this case would suggest that the buyer could have brought an action on the contract had the seller defaulted, and the seller would have heen precluded from asserting the Statute as a defense.

94 See, e.g., Booth v. A. Levy \& J. Zentner Co. supra note 90.

$9535 \mathrm{Cal} .2 \mathrm{~d}$ at 623,220 P.2d at 739 (1950).

96 See, e.g., Ruinello v. Murray, 36 Cal. 2d 687, 227 P.2d 251 (1951); Fallon v. American Trust Co., 176 Cal. App. 2d 381, 1 Cal. Rptr. 386 (1959).

07 See Goldstein v. McNeil, 122 Cal. App. 2d 608, 265 P.2d 113 (1954). Perhaps the cost of hitigation in most cases prohibits the bringing of actions which involve a less than substantial injury to the plaintiff; certainly an appeal in such a case is unlikely.

98 See text accompanying notes 60-61 supra.

99 The courts have frequently stated that the doctrine of estoppel is not limited to any 
tract to make a will and the normal commercial contract. In the former there is perhaps the greatest possibility for fraud to occur, while at the same time, such contracts are seldom reduced to writing, the parties frequently being unaware of the need for such writing.

This dilemma posed by the application of the Statute of Frauds to contracts to make wills suggests that the courts should treat these cases differently than the commercial contracts. This is in fact what the courts have done from the standpoint of what is required in the way of injury to the plaintiff. ${ }^{100}$ To the extent that Monarco has resulted in a wide opening of the door to judicial enforcement of contracts otherwise barred by the Statute, it has been primarily in the area of the will cases. Although it is perhaps too early to conclude what the effect of Monarco has been in the commercial agreements, the cases indicate that the courts are less inchined to expand the estoppel doctrine in the commercial area. ${ }^{101}$

From the standpoint of what is required on the part of the defendant, there seems to be no distinction on the basis of the type of transaction. In all of the cases in which an oral agreement covered by the Statute of Frauds has been enforced, there has been conduct by the defendant subsequent to the oral agreement which at least could imply the existence of the contract. ${ }^{102} \mathrm{~A}$ distinction must be made, however, between what the courts have done factually and how they have analyzed their decisions. Generally, the courts have neither addressed themselves to whether such conduct was essential nor have they emphasized the relationship between such conduct and the existence of the contract. ${ }^{103}$

The courts are frequently silent regarding the purposes underlying the Statute of Frauds, ${ }^{104}$ and generally dispose of the cases within the broad test set forth in Monarco. ${ }^{105}$ The Monarco test has been applied

particular transaction. See, e.g., Seymour v. Oelrichs, 156 Cal. 782, 106 Pac. 88 (1909); Moore v. Day, 123 Cal. App. 2d 134, 266 P.2d 51 (1954).

100 See text accompanying notes 45-98 supra.

101 See, e.g., Ruinello v. Murray, 36 Cal. 2d 687, 227 P.2d 251 (1951) ; Pacific Southwest Dev. Corp. v. Western Pac. R.R., 47 Cal. 2d 62, 301 P.2d 825 (1956). But see Goldstein v. McNeil, 122 Cal. App. 2d 608, 265 P.2d 113 (1954).

102 See text accompanying notes 40-41 supra.

103 See text accompanying notes 42-43 supra.

104 In Pacific Southwest Dev. Corp. v. Western Pac. R.R., 47 Cal. 2d 62, 301 P.2d 825 (1956), the court indicates a concern with vindication of the purposes for the Statute, while in Sunset-Sternau Food Co. v. Bonzi, 60 Cal. 2d 834, 389 P.2d 133, 36 Cal. Rptr. 741 (1964), the court indicates a lack of confidence in the viability of the purposes of the Statute. The development of the doctrine of estoppel is perhaps a reflection of this lack of confidence in the usefulness of the Statute more than anything else.

In rejecting section 2-201(3)(b) of the Uniform Commercial Code, one of the reasons proffered by the Senate Fact Finding Committee on Judiciary, note 114 infra, was that the purpose of this code section was to prevent the enforcement of contracts which were not made. Interestingly enough the committee report did not suggest another purpose.

105 Compare Monarco v. Lo Greco, 35 Cal. 2d 621, 220 P.2d 737 (1950), with Miller v. 
on a case-by-case basis with one effect being to make predictability of what constitutes an "unconscionable injury" somewhat uncertain. ${ }^{100}$

That the test in Monarco is stated so generally suggests consideration of the distribution of functions between the appellate and trial courts in resolving these cases. It would appear that the appellate courts have largely left to the trial courts the determination of whether the doctrine of estoppel should be apphed in a particular case. The most radical illustration of this was in Goldstein v. $M c N e i{ }^{107}$ where the court held that whether the doctrine of estoppel was applicable in a particular case was a question of fact and the appellate court's scope of review was limited to determining whether the trial court had abused its discretion. It is doubtful whether this decision accurately reflects the law in this regard. Usually the courts have not felt so restricted in reviewing this question, ${ }^{108}$ but it should be noted that the appellate courts have not reversed one judgment for the plaintiff since the Monarco case was decided. By virtue of affirming some judgments sustaining the defendant's demurrer, however, the appellate courts have given some direction on the issue of what the requirements are for applying the doctrine of estoppel. ${ }^{109}$

Since the test in Monarco is so general, the trial courts have considerable flexibility to determine whether to enforce the Statute in a given case. While this makes predictability uncertain, it affords the trial court the opportunity to consider the whole spectrum of factors which might be relevant to balancing the adequacy of the fact determination process agamst the purposes of the Statute. Such freedom for the trial court is justifiable if trial procedure has advanced to sucli an extent that it is adequate to protect against the evils whicl the Statute sought to prevent. Where trials are before judges rather than juries, perhaps the protection is even greater than where the trial is before a jury. It

Rau, 216 Cal. App. 2d 68, 30 Cal. Rptr. 612 (1963). The latter, which did not involve the Statute of Frauds, sets forth the elements of estoppel as follows: "Four elements are essential before estoppel is present: (1) a representation of fact with intent that it will be acted upon; (2) the party to be estopped must know the true facts; (3) the innocent party must be ignorant of the facts; and (4) the innocent party must reasonably rely to his injury on the representations."

106 See Macaulay, Justice Traynor and the Law of Contracts, 13 Stan. L. Rev. 812, 828 n.46 (1961): "The new position calls for a case-by-case definition of when reliance is 'unconscionable' and when enrichment is 'unjust.' The determination appears to be largely intuitive."

107122 Cal. App. 2d 608, 265 P.2d 113 (1954).

108 See, e.g., Monarco v. Lo Greco, 35 Cal. 2d 621, 220 P.2d 737 (1950); Ward v. Wrixon, 168 Cal. App. 2d 642, 336 P.2d 640 (1959).

109 See Chabon v. Schneider, 117 Cal. App. 2d 334, 256 P.2d 54 (1953); Jirschik v. Farmers \& Merchants Nat'l Bank of Los Angeles, 107 Cal. App. 2d 405, 237 P.2d 49 (1951). 
must be recognized, however, that there is a lack of empirical evidence bearmg on this question.

If the above is an accurate description of what the courts have done, then a number of questions are suggested. Why deny recovery where the plaintiff only has an expectancy interest or limit him to restitution where the defendant has been unjustly enriched? Why should the Statute be strictly applied in the case of contracts for the employment of real estate agents and not in other instances? In the case of contracts to make wills, why should recovery on the contract be granted where the services are unique and denied where they are not? Such distinctions and limitations make little sense if the inarticulate premise underlying the extension of the estoppel doctrine is that the Statute no longer serves a useful purpose. The explanation for what the courts have done must largely be based on speculation. The courts have gone about as far as possible towards abrogating the Statute of Frauds consistent with the presence of the Statute on the books. Some of the questions may be explained on the basis of the court utilizing already existing common law and equitable principles in the development of the estoppel doctrine. Moreover, by the retention of the Statute on the books and the recognition of some limitations to the estoppel doctrine, some of the prophylactic function of the Statute is preserved, especially its in terrorem effect.

There are more direct techniques for dealing with the basic evidentiary problem presented by oral agreements. One such method would be the requiring of a higher standard of proof to establish the oral contract. ${ }^{110}$ Another possibility would be to require that the defendant deny the contract as a prerequisite to raising the Statute as a defense. ${ }^{111}$ This proposal would directly counter the illegitimate use of the Statute of Frauds to avoid contracts which are no longer attractive to the defendant. ${ }^{112}$ The California Legislature rejected section 2-201(3)(b) of the Uniform Commercial Code, which provides that the contract would be enforceable "if the party against whom enforcement is sought admits in his pleading, testimony or otherwise in court that a contract for sale was made, but the contract is not enforceable under this provision beyond the quantity of goods admitted." 113 The principal reason for rejecting this section was the uncertainty of its effect on well estabhished pleading

110 See Summers, supra note 5 , at 464 . While such a change in the standard of proof would doubtless focus attention upon the evidentiary issue, it is difficult to say whether it would produce a discernible effect.

111 See 2 Corbin, Contracts § 275, at 13 (1950).

112 See text accompanying note 14 supra.

113 UnIForar Commercial CODE \& 2-201(3) (b). 
practices in California. ${ }^{114}$ The section is not clear whether the defendant's demurrer would be deemed an admission of the oral contract. Furthermore, it is not clear whether the defendant could have been compelled to testify whether a contract was formed. ${ }^{115}$ If the Legislature were in agreement with the desirability of barring the defense of the Statute of Frauds unless the defendant was prepared to deny the contract, however, the procedural ambiguities and difficulties could easily be resolved. ${ }^{116}$ It is unfortunate that the Legislature did not choose to do so, for this section would have been a salutary addition, not only in sale of goods transactions, but in all transactions within the Statute.

The extension of the estoppel doctrine in California is apparently based upon confidence by the courts in the fact determination process. This sub rosa erosion of the Statute of Frauds by the courts does preserve some of the prophylactic function of the Statute, since it remains on the books and the courts have retained sone limitations to the application of the estoppel doctrine. As mentioned above, however, the limitation of recovery to quantum meruit where this remedy is available and denying recovery entirely where only the plaintiff's expectancy interest is involved, produces liarsh results if we assume the fact determination process is adequate. If the confidence in the fact determination process is warranted, then such limitations are a ratlier higl price to pay to preserve the prophylactic function of the Statute-a function which with the passage of time lias become more speculative than real.

Frederick Innes Fox

114 See The Uniform Commercial Code, Sixtr Report to the Legistature, Senate Fact Finding Comanitiee on Judicrarx, pt. I, at 448-50 (1959-1961); California State Bar Committee on the Commercial Code, $A$ Special Report, The Uniform Commercial Code, 37 CaL. S.B.J. 117, 141-42 (1962).

115 See Holahan, Contract Formalities and the Uniform Commercial Code, 3 Vnr. L. REv. 1, 17-18 (1957).

116 Under existing law it seems that if the defendant admits the existence of a contract in an answer or cross-complaint that such admission will constitute a sufficient memorandum. Accord, Walsh v. Standart, $174 \mathrm{Cal} .807,164 \mathrm{Pac} .795$ (1917). The memorandum requirement may be satisfied by a reference to the contract in another writing subsequent to the original contract. Dunham, Carrigan \& Hayden Co. v. Thermoid Rubber Co., 84 Cal. App. 669, 258 Pac. 663 (1927). 